
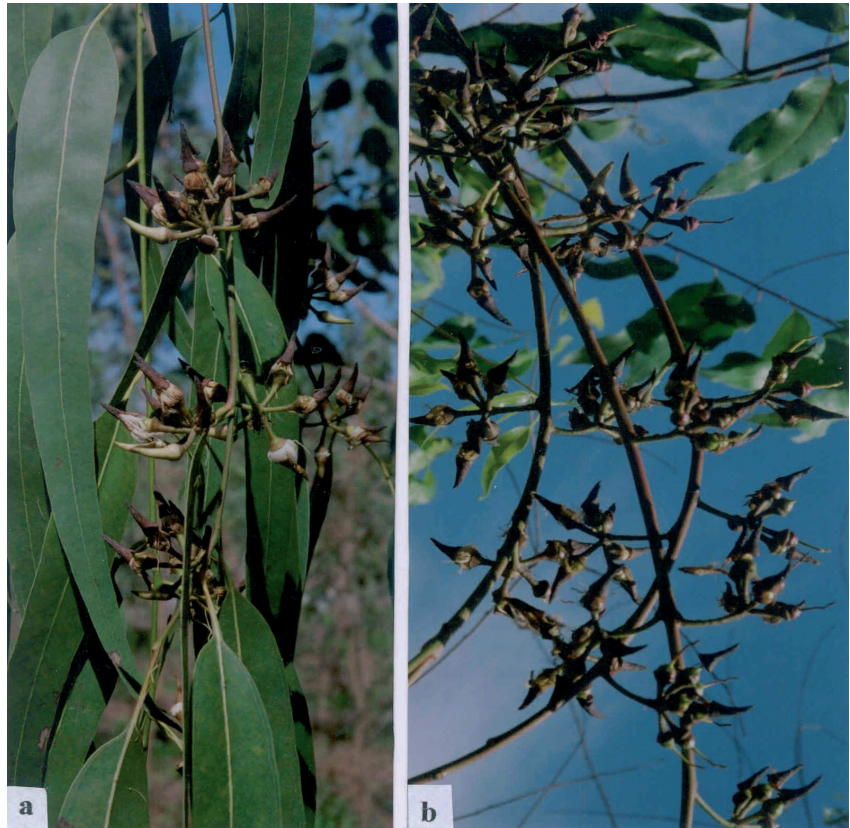

Figure 1. - (a) A portion of branch of E. tereticornis showing cleistogamous flowers. (b) Close up view of a branch showing development of fruits from cleistogamous flowers. Note that the opercula are still sitting on withered stigmas even after one month of fruit formation.

flowers. Our studies suggest that this cleistogamous family may also suffer inbreeding depression.

An assessment made for growth parameters viz. height and collar diameter of provenances/families at age 18 months revealed that this particular provenance/family performed poorly in relation to others. It ranked last but one in position with regard to height and diameter. For height and diameter, respectively it was 46.6 and $42.8 \%$ inferior to the best performing provenance/family and 18.9 and $24.5 \%$ inferior to the pooled means of the provenances. In general all 32 plants were poor in respect of growth performance. In addition, out of 32 plants, only 15 were found to initiate flowers at the age of 18 months.

\section{Acknowledgement}

The authors are grateful to Dr. Chris HaRwood, Australian Seed Centre, CSIRO, Canberra, Australia for providing seed lots of Eucalyptus tereticornis.

\section{References}

Barber, H. N. (1954): A sterile eucalypt. Papers and Proceedings of the Royal Society of Tasmania 88: 285-287.

EldRIDGe, K. G., J. Davidson, C. HaRwood and G. VAN WYK (1993): Eucalypts domestication and breeding. Oxford University Press, Oxford.

FRYXELL, P. A. (1957): Mode of reproduction of higher plants. Botanical Review 23: 135-233.

PENFold, A. R. and J. L. Willis (1961): The Eucalyptus Leonard Hill London and Inter Science Publication, New York.

Potts, B. M., R. C. Barbour, A. B. Hingston and R. E. VAILlancourt (2003): Turner Review No. 6 Genetic pollution of native eucalypt gene pools - identifying the risks. Australian Journal of Botany 51: 1-25.

PRYOR, L. D. (1976): The Biology of Eucalyptus, Edward Arnold, London.

VenKatesh, C. S. (1971): Cleistogamy in Eucalyptus tereticornis Sm. Paper presented at IUFRO working group meeting, Gainesville, Fla. USA, March, 14-20.

Venkatesh, C. S., R. S. ArYa and V. K. Sharma (1973): Natural selfing in planted Eucalyptus and its estimation. Journal Plantation Crops 1: 23-25.

\title{
Soil Temperature and Precipitation Affect the Rooting Ability of Dormant Hardwood Cuttings of Populus
}

\author{
By R. S. Zalesny JR. ${ }^{1, *)}$, R. B. Hall ${ }^{2)}$, E. O. BAueR ${ }^{1)}$, and D. E. RIemenschneideR ${ }^{1)}$
}

(Received 23 $3^{\text {rd }}$ December 2004)

\begin{abstract}
In addition to genetic control, responses to environmental stimuli affect the success of rooting. Our objectives were to: 1) assess the variation in rooting ability among 21 Populus clones grown under varying soil tem-

\footnotetext{
1) USDA Forest Service, North Central Research Station, Forestry Sciences Laboratory, 5985 Highway K, Rhinelander, WI 54501, U.S.A.

$\left.{ }^{2}\right)$ Iowa State University, Department of Natural Resource Ecology and Management, 339 Science II, Ames, IA 50011, U. S. A.

*) Corresponding author (research plant geneticist); Phone: (715) 362-1132; Fax: (715) 362-1166; E-mail: rzalesny@fs.fed.us
}

peratures and amounts of precipitation and 2) identify combinations of soil temperature and precipitation that promote rooting. The clones belonged to five genomic groups ([P. trichocarpa Torr. \& Gray $\times$ P. deltoides Bartr. ex Marsh] x P. deltoides 'BC'; $P$. deltoides 'D'; $P$. deltoides $\times P$. maximowiczii A. Henry 'DM'; $P$. deltoides $\times$ P. nigra L. 'DN'; $P$. nigra $\times$ P. maximowiczii 'NM'). Cuttings, 20 $\mathrm{cm}$ long, were planted in Iowa and Minnesota, USA, in randomized complete blocks at 1.2- x 2.4-m spacing across three planting dates during 2001 and 2002. Soil temperatures were converted to belowground growing degree days (GDD) (base temperature $=10^{\circ} \mathrm{C}$ ) accumulated over 14 days. Genomic groups responded similarly 
for root dry weight, number of roots, total root length, and mean root length, that increased as belowground GDD increased. Belowground GDD and precipitation governed rooting throughout the 14-d growing period. A minimum of four days above $14^{\circ} \mathrm{C}$, along with sufficiently dispersed precipitation (e.g. no more than $3 \mathrm{~d}$ without a precipitation event), were needed to sustain aboveaverage rooting. Therefore, we recommend using a base temperature of $14{ }^{\circ} \mathrm{C}$ for future models estimating belowground GDD in northern temperate zones.

Key words: hybrid poplar, growing degree days, adventitious rooting, Populus deltoides, $P$. nigra, $P$. maximowiczii, $P$. trichocarpa.

\section{Introduction}

The potential for the production of alternative fuels as a source of energy is increasing in North America (HUSAIN et al., 1998). Intensively cultured poplar (Рориlus spp. and hybrids) plantations also provide industries with alternative fiber supplies. Four commonly used poplar species in North America are: eastern cottonwood (P. deltoides Bartr. ex Marsh), western black cottonwood (P. trichocarpa Torr. \& Gray), European black poplar (P. nigra L.), and Japanese poplar ( $P$. maximowiczii A. Henry). Poplars grow approximately 6 to 8 times faster than native aspen in the North Central United

Table 1. - Genomic groups, clones, and their origin in an experiment testing poplar (Populus spp.) clones in their ability to develop roots from dormant hardwood cuttings.

\begin{tabular}{|c|c|c|}
\hline Genomic group & Clone & Origin \\
\hline (P. trichocarpa $\times$ P. deltoides $)$ & $\mathrm{NC} 13563$ & D. Riemenschneider, U.S. Forest Service \\
\hline$\times P$. deltoides & $\mathrm{NC} 13570$ & $"$ \\
\hline \multirow[t]{4}{*}{ (BC) } & $\mathrm{NC} 13624$ & $"$ \\
\hline & NC13649 & $"$ \\
\hline & NC13686 & $"$ \\
\hline & $\mathrm{NC} 14042$ & $"$ \\
\hline$P$. deltoides & D110 & C. Mohn, Univ. of Minnesota \\
\hline \multirow[t]{3}{*}{ (D) } & D105 & $"$ \\
\hline & D117 & $"$ \\
\hline & D133 & $"$ \\
\hline$P$. deltoides $\times$ P. maximowiczii & 25 & V. Steenacker, Belgium \\
\hline \multirow[t]{4}{*}{$(\mathrm{DM})$} & DM105 & C. Mohn, Univ. of Minnesota and \\
\hline & $\mathrm{NC} 14103$ & D. Riemenschneider, U.S. Forest Service \\
\hline & $\mathrm{NC} 14105$ & $"$ \\
\hline & $\mathrm{NC} 14106$ & $"$ \\
\hline$P$. deltoides $\times$ P. nigra & DN17 & France, a.k.a. 'Robusta' \\
\hline \multirow[t]{3}{*}{$(\mathrm{DN})^{a}$} & DN34 & Europe, a.k.a. 'Eugenei' \\
\hline & DN5 & Netherlands, a.k.a. 'Gelrica' \\
\hline & DN70 & Europe \\
\hline$P$. nigra $\times P$. maximowiczii & NM2 & Germany \\
\hline$(\mathrm{NM})$ & NM6 & Germany \\
\hline
\end{tabular}

Note: Authorities for the aforementioned species are: $P$. deltoides Bartr. ex Marsh; P. trichocarpa Torr. \& Gray; P. maximowiczii A. Henry; P. nigra L.

${ }^{a}$ Euramerican hybrids with the common designations of $P$. x euramericana Guin. and P. $\mathrm{x}$ canadensis Moench. 
States. Aboveground stand productivity of poplar is estimated between 27 to $45 \mathrm{~m}^{3} \cdot \mathrm{ha}^{-1} \cdot \mathrm{yr}^{-1}$, compared with native aspen ( $P$. tremuloides Michx. and $P$. grandidentata Michx.) stand productivity of 4 to $6 \mathrm{~m}^{3} \cdot \mathrm{ha}^{-1} \cdot \mathrm{yr}^{-1}$ (NETZER et al., 2002; RIEMENSCHNEIDER et al., 2001).

Successful establishment of poplar plantations depends upon adequate rooting from hardwood cuttings planted as dormant unrooted stock (ZALESNY et al., 2003; StanturF et al., 2001; RIEMENSCHNEIDER and BAUER, 1997; HANSEN et al., 1993). Although additional studies are needed (reviewed by HAISsIG and DAVIS, 1994; HAISSIG et al., 1992), the genetics underlying the ability of poplar genotypes to root from cuttings have been studied (BRADSHAW, 1996; RIEMENSCHNEIDER et al., 1996; WILCOX and FARMER, 1968). The physiology of poplar rooting also needs to be investigated more thoroughly (DAVIES and HARTMANN, 1988). Edaphic factors such as soil temperature, soil moisture, soil strength, and soil aeration play a major role in governing the rooting of poplar cuttings.

Generally accepted air temperature ranges for optimum root growth include 18 to $32^{\circ} \mathrm{C}$ day and 5 to $15^{\circ} \mathrm{C}$ night (Hartmann et al., 1997; Preece, 1993; Dykeman, 1976). Although some rooting takes place at soil temperatures below $10^{\circ} \mathrm{C}$ (LANDHÄUSSER et al., 2002; DOMISCH et al., 2001; Vinocur and Ritchie, 2001; PAVEL and FERERES, 1998; FENNELL et al., 1990), successful rooting is sustained only at soil temperatures above this threshold (LANDHÄUSSER et al., 2001; WAN et al., 1999; HANSEN, 1986; JENKINSON, 1980). KESTER (1970) stated the minimum temperature in a 24-hour period often governed rooting.

Soil moisture levels during or directly following planting are important for successful rooting of cuttings (Tschaplinski et al., 1998; BlOOMBERG, 1963). Allen and McCoмв (1956) planted $P$. deltoides cuttings in five different soil moisture regimes ranging from below field capacity to saturation. They found the percent of cuttings rooted $(0 \%$ to $80 \%)$ and the number of roots per cutting (2 to 20) increased with increasing soil moisture up to the point of saturation. Soaking cuttings in water until roots begin to initiate is a common pre-planting treatment that increases the success of rooting under conditions of low soil moisture content (DEsROCHERS and Thomas, 2003; Hansen, 1986; Hansen and Phipps, 1983; Phipps et al., 1983; PETERsEN and PhipPs, 1976).

The objectives of this study were to: 1 ) assess the variation in rooting ability among 21 Populus clones belonging to five genomic groups grown under varying soil temperatures and amounts of precipitation in a field setting and 2) identify combinations of soil temperature and precipitation that promote rooting.

\section{Materials and Methods}

\section{Clone and site selection}

Clone and site selection were described in greater detail by ZALESNY et al. (2005) and ZALESNY (2003). In summary, twenty-one clones (Table 1) were selected across the current range of clones from five Populus genomic groups in December 2000 based on their growth potential and anticipated range of rooting abilities. The clones were treated as random in the analysis in order to calculate variance components, which were used for estimates of heritability (ZALESNY et al., 2005; ZALESNY, 2003). One-year-old shoots were collected from stool beds established at Hugo Sauer Nursery in Rhinelander, Wisconsin, USA $\left(45.6^{\circ} \mathrm{N}, 89.4^{\circ} \mathrm{W}\right)$. Cuttings, $20 \mathrm{~cm}$ long and ranging in diameter from 0.3 to $1.6 \mathrm{~cm}$, were prepared during December and January of 2001 and 2002, with cuts made to position at least one primary bud not more than $2.54 \mathrm{~cm}$ from the top of each cutting. Cuttings were stored in polyethylene bags at $5{ }^{\circ} \mathrm{C}$ until each planting date during May and June of 2001 and 2002. Cuttings were soaked in water for $3 \mathrm{~d}$ before planting to a maximum depth of $18 \mathrm{~cm}$. There were three planting dates (across May and June) for each combination of year and site. Test plots were established at Ames, Iowa, USA $\left(42.0^{\circ} \mathrm{N}, 93.6^{\circ} \mathrm{W}\right)$; Waseca, Minnesota, USA $\left(44.1^{\circ} \mathrm{N}, 93.5^{\circ} \mathrm{W}\right)$; and Westport, Minnesota, USA $\left(45.7^{\circ} \mathrm{N}, 95.2^{\circ} \mathrm{W}\right)$. Sites were chosen because of their inclusion in a Populus Regional Testing Program (RIEMENSCHNEIDER et al., 2001), and because they represented a latitudinal gradient from central Iowa to central Minnesota and a range of soil types typical of hybrid poplar plantations. The soils of Ames, Waseca, and Westport were Hanlon fine sandy loam (fine-loamy, mixed, mesic Cumulic Hapludolls), Clarion loam (fineloamy, mixed, mesic Typic Hapludolls)/Webster clay loam (fine-loamy, mixed, mesic Typic Haplaquolls), and Estherville sandy loam (sandy, mixed, mesic Typic Hapludolls), respectively. Mean annual air temperature, precipitation, and growing degree days (base temperature $=$ $12.8^{\circ} \mathrm{C}$ ) and median annual number of days in the growing season (base temperature $=0{ }^{\circ} \mathrm{C}$ ) for Ames are $9.2^{\circ} \mathrm{C}, 86.5 \mathrm{~cm}, 2281$, and 162 , respectively; while these data for Waseca are $6.6^{\circ} \mathrm{C}, 88.2 \mathrm{~cm}, 1808$, and 150 , respectively; and these data for Westport are $5.8^{\circ} \mathrm{C}$, $64.5 \mathrm{~cm}, 1596$, and 144, respectively.

The experimental design was randomized complete blocks with 12 blocks per planting date and one ramet per clone per block. Blocking occurred perpendicular to slope gradients, where possible. Spacing was $1.2 \times 2.4 \mathrm{~m}$ between cuttings. Two border rows containing clones DN34 and NM2 were established at all plantings, except at Westport in 2002, where only one border row of clone NM2 was planted due to spatial constraints.

Based on prior indications that soil temperature affects rooting (ZALESNY et al., 2004; 2000), and recommendations to plant when soil temperature reaches $10^{\circ} \mathrm{C}$ (HANsEN et al., 1993; HANSEN, 1986), we attempted to begin planting when nighttime soil temperatures reached this threshold. However, this protocol was not maintained given erratic weather conditions, extreme fluctuations in soil temperatures, and required logistics.

\section{Measurements}

Measurements were described in greater detail by ZALESNY et al. (2005) and ZALESNY (2003). In summary, environmental data were collected at 15 -minute intervals throughout each growing season. $\mathrm{HOBO}^{\circledR} \mathrm{H} 8$ Pro Series data loggers (Onset Corporation, Bourne, Massachusetts) were used to record relative humidity, soil 
temperature at a depth of $20 \mathrm{~cm}$, and air temperature in the shade at $1 \mathrm{~m}$ above the ground. Precipitation data were recorded daily.

Individual trees were harvested $14 \mathrm{~d}$ after planting. A soil mass up to $65 \mathrm{~cm}$ in diameter and $40 \mathrm{~cm}$ deep around the developing cutting was excavated. Roots were isolated by washing and photographed with a computerized image-capturing system. Images were stored on high-resolution (High 8 format) video tape and subsequently converted to 8-bit grayscale Tagged Image File
Format (TIFF). The TIFF images were analyzed with Optimas $^{\mathrm{TM}} 6.2$ image analysis software (Optimas Corporation, Bothell, Washington) to determine dimensions and numbers of leaves and roots. Leaves, stems, lateral roots, callus, and callus roots were dissected from each cutting, bagged, and dried at $70^{\circ} \mathrm{C}$ for dry weight determination. Callus roots, which differentiate from callus at the base of the cutting in response to wounding, were considered negligible because only 15 callus roots were produced over the entire experiment. Thus, subsequent

Table 2. - Regression equation coefficients and derived statistics for mean root length $(\mathrm{cm})$ of five poplar genomic groups in an experiment testing clones in their ability to develop roots from dormant hardwood cuttings when planted at Ames, Iowa, USA $\left(42.0^{\circ} \mathrm{N}, 93.6^{\circ} \mathrm{W}\right)$; Waseca, Minnesota, USA $\left(44.1^{\circ} \mathrm{N}, 93.5^{\circ} \mathrm{W}\right)$; and Westport, Minnesota, USA $\left(45.7^{\circ} \mathrm{N}, 95.2^{\circ} \mathrm{W}\right)$ during 2001 and 2002 . Genomic groups are: $\mathrm{BC}=(P$. trichocarpa $\times P$. deltoides $) \times P$. deltoides $; \mathrm{D}=P$. deltoides; $\mathrm{DM}=P$. deltoides $\times P$. maximowiczii $; \mathrm{DN}=P$. deltoides $\times$ P. nigra $; \mathrm{NM}=P$. nigra $\times$ P. maximowiczii.

\begin{tabular}{lcccccccc}
\hline & \multicolumn{7}{c}{ Mean root length $=y+z$ (Belowground growing degree days) } \\
\cline { 2 - 8 } Genomic group & $\mathrm{n}$ & $r^{2}$ & $P$-value & $\mathrm{y}$ & $\mathrm{z}$ & $\mathrm{P}_{\min }{ }^{a}$ & $\mathrm{P}_{\max }{ }^{b}$ \\
\hline $\mathrm{BC}$ & 1296 & 0.37 & $\mathbf{0 . 0 1 3 2}$ & 0.9854 & 0.0128 & 0.99 & 2.11 \\
$\mathrm{D}$ & 864 & 0.29 & $\mathbf{0 . 0 3 1 8}$ & 0.9420 & 0.0108 & 0.94 & 1.89 \\
$\mathrm{DM}$ & 1080 & 0.33 & $\mathbf{0 . 0 2 0 2}$ & 0.9254 & 0.0103 & 0.93 & 1.83 \\
$\mathrm{DN}$ & 864 & 0.33 & $\mathbf{0 . 0 1 9 2}$ & 1.0613 & 0.0110 & 1.06 & 2.03 \\
$\mathrm{NM}$ & 432 & 0.44 & $\mathbf{0 . 0 0 4 8}$ & 0.8328 & 0.0148 & 0.83 & 2.14 \\
\hline
\end{tabular}

Note: Authorities for the aforementioned species are: P. deltoides Bartr. ex Marsh; P. trichocarpa Torr. \& Gray; P. maximowiczii A. Henry; P. nigra L.

${ }^{a} \mathrm{P}_{\min }=$ predicted minimum mean root length.

${ }^{b} \mathrm{P}_{\max }^{\min }=$ predicted maximum mean root length.

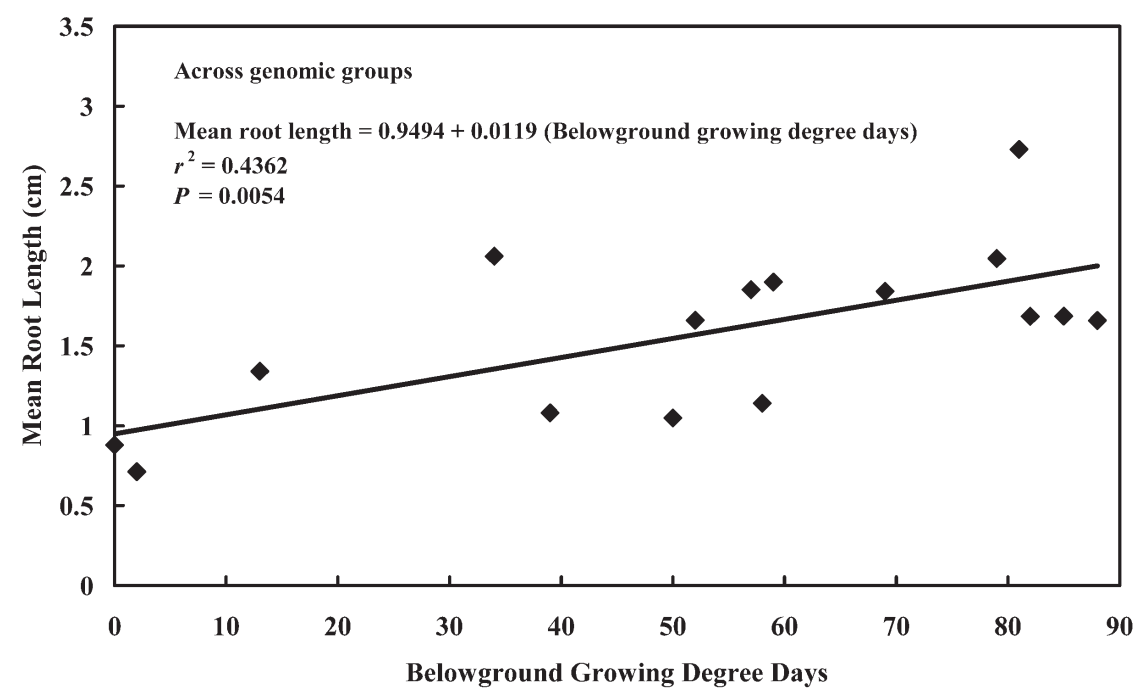

Figure 1. - Mean root length versus belowground growing degree days across five poplar genomic groups in an experiment testing clones in their ability to develop roots from dormant hardwood cuttings. Points represent the mean of $n=252$ cuttings, except for those of 33 and 69 growing degree days, which represent twice the number due to similar belowground growing degree days at two combinations of site and planting date. 
rooting variables refer to lateral roots only. Lateral roots differentiate from lateral primordia distributed throughout the length of the cutting.

\section{Data analysis}

Data on root dry weight, number of roots, total root length, and mean root length were subjected to analysis of variance according to $\mathrm{SAS}^{\circledR}$ (PROC GLM and PROC VARCOMP; SAS InstITUTE, InC., 2000) on multiple-year (Model I) and single-year (Model II) bases assuming all random effects and were described by ZALESNY et al. (2005). Interaction terms with $P \geq 0.25$ from the original model containing all potential main and interaction effects were pooled with the residual error term to increase precision of $\mathrm{F}$-tests.

Planting date was used as a surrogate measure of soil temperature and served the purpose of creating a classification variable associated with belowground growing degree days (GDD). Growing degree days have been used in the plant sciences to predict growth, harvest dates, insect outbreaks, and other biological phenomena (DunN et al., 1996; EisEnsmith et al., 1980; NEWMAN et al., 1968). ZALESNY et al. (2004) defined growing degree days as the sum of the average temperature in a 24hour period minus a base temperature, where the base temperature equals a threshold that supports adequate
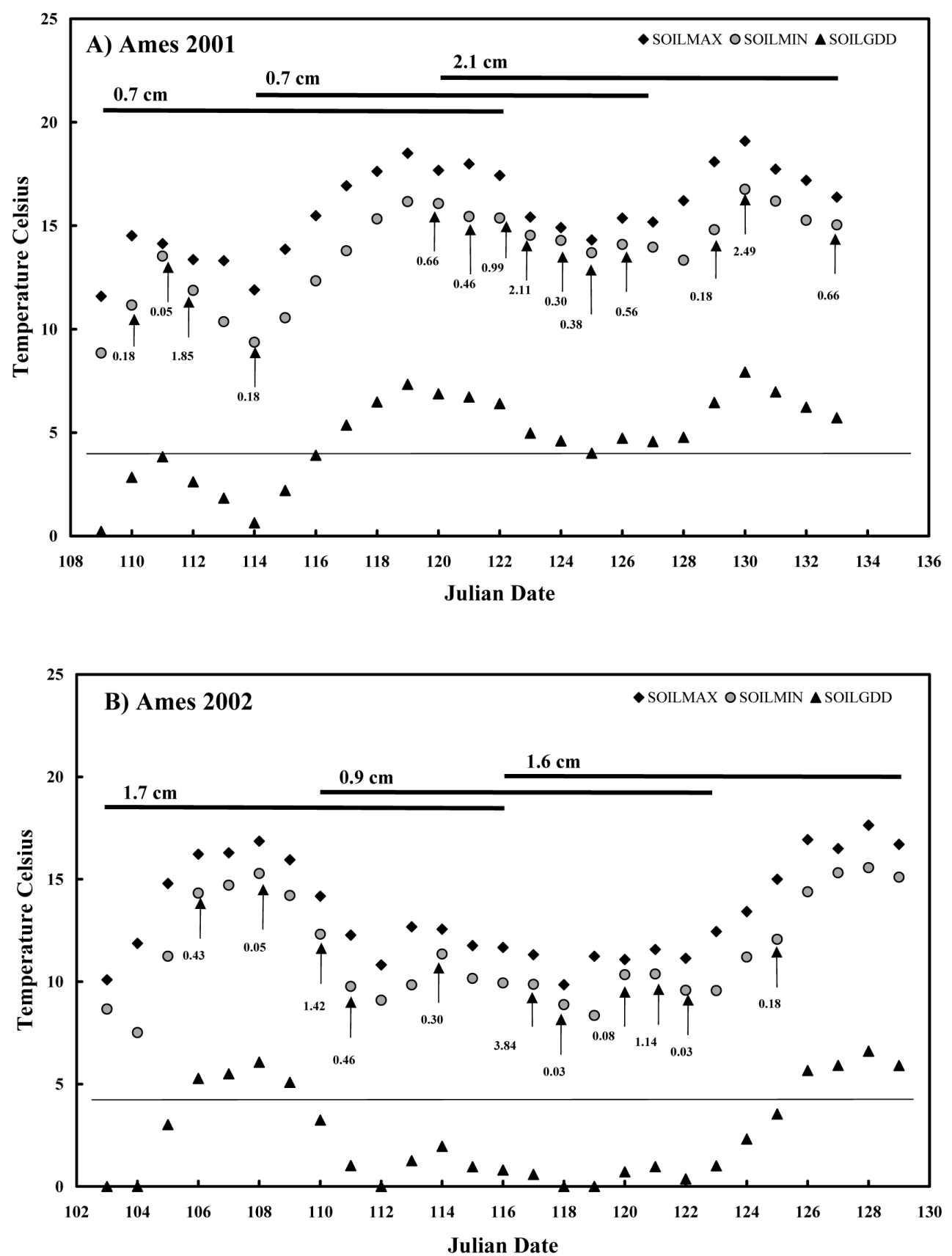

Figure 2. - Maximum soil temperature (SOILMAX), minimum soil temperature (SOILMIN), belowground growing degree days (SOILGDD), and precipitation events (denoted with value in $\mathrm{cm}$ below each arrow) at Ames, Iowa, USA $\left(42.0^{\circ} \mathrm{N}, 93.6^{\circ} \mathrm{W}\right)$ during $2001(\mathrm{~A})$ and $2002(\mathrm{~B})$. Each black bar on the top of the figure represents one planting date, with the mean root length of 252 cuttings listed above it. 
Table 3. - Mean root length, number of days above $14^{\circ} \mathrm{C}$, and total precipitation for each combination of year, site, and planting date in an experiment testing five poplar genomic groups in their ability to develop roots from dormant hardwood cuttings. Mean root length is estimated across genomic groups, $n=252$ cuttings. Standard errors are in parentheses.

\begin{tabular}{|c|c|c|c|c|c|c|c|}
\hline Rank & Year & Site & $\begin{array}{r}\text { Planting } \\
\text { date }^{a}\end{array}$ & $\begin{array}{l}\text { Mean root } \\
\text { length }(\mathrm{cm})\end{array}$ & $\begin{array}{r}\text { Number of } \\
\text { days above } \\
14{ }^{\circ} \mathrm{C}\end{array}$ & $\begin{array}{r}\text { Total } \\
\text { precipitation } \\
(\mathrm{cm})^{b}\end{array}$ & Comments \\
\hline 1 & 2001 & Ames & 3 & $2.1(0.12)$ & 14 & 8.8 & $\begin{array}{l}\text { High precipitation dispersed throughout } \\
\text { growth period. }\end{array}$ \\
\hline 2 & 2002 & Ames & 1 & $1.7(0.11)$ & 4 & 2.7 & $\begin{array}{l}\text { Low precipitation dispersed throughout } \\
\text { growth period. }\end{array}$ \\
\hline 3 & 2002 & Ames & 3 & $1.6(0.08)$ & 5 & 5.3 & $\begin{array}{l}\text { High precipitation dispersed throughout } \\
\text { growth period. }\end{array}$ \\
\hline 4 & 2001 & Waseca & 3 & $1.3(0.07)$ & 8 & 3.6 & $\begin{array}{l}\text { Moderate precipitation at beginning; very } \\
\text { low precipitation throughout final nine } \\
\text { days. }\end{array}$ \\
\hline 5 & 2001 & Waseca & 1 & $1.1(0.09)$ & 10 & 6.6 & $\begin{array}{l}\text { High precipitation at beginning and end; } \\
\text { high soil temperatures. }\end{array}$ \\
\hline 5 & 2002 & Westport & 3 & $1.1(0.08)$ & 11 & 0.7 & $\begin{array}{l}\text { Low precipitation dispersed throughout } \\
\text { growth period; high soil temperatures. }\end{array}$ \\
\hline 6 & 2002 & Waseca & 3 & $1.0(0.07)$ & 14 & 8.3 & $\begin{array}{l}\text { High precipitation dispersed throughout } \\
\text { growth period; excess at end. }\end{array}$ \\
\hline 7 & 2001 & Westport & 2 & $0.9(0.08)$ & 7 & 5.2 & $\begin{array}{l}\text { High precipitation dispersed throughout } \\
\text { growth period. }\end{array}$ \\
\hline 7 & 2002 & Ames & 2 & $0.9(0.06)$ & 0 & 7.3 & $\begin{array}{l}\text { High precipitation; inadequate soil } \\
\text { temperatures. }\end{array}$ \\
\hline 8 & 2001 & Westport & 3 & $0.8(0.05)$ & 7 & 5.0 & $\begin{array}{l}\text { Low precipitation at end, very low soil } \\
\text { temperatures at beginning. }\end{array}$ \\
\hline 8 & 2001 & Westport & 1 & $0.8(0.08)$ & 11 & 3.4 & $\begin{array}{l}\text { Low precipitation at beginning; high soil } \\
\text { temperatures. }\end{array}$ \\
\hline 9 & 2001 & Ames & 1 & $0.7(0.09)$ & 8 & 4.4 & $\begin{array}{l}\text { Low precipitation at beginning and end; } \\
\text { nothing in the middle. }\end{array}$ \\
\hline 9 & 2001 & Waseca & 2 & $0.7(0.08)$ & 8 & 8.3 & $\begin{array}{l}\text { High precipitation in middle; low } \\
\text { precipitation at beginning and end. }\end{array}$ \\
\hline 9 & 2002 & Waseca & 2 & $0.7(0.05)$ & 7 & 1.8 & $\begin{array}{l}\text { Low precipitation at beginning; moderate } \\
\text { precipitation during final five days. }\end{array}$ \\
\hline
\end{tabular}

\footnotetext{
${ }^{a}$ Planting dates 1, 2, and 3 were as follows: Ames 2001 - 19 April, 24 April, 30 April; Ames 2002 - 13 April, 20 April, 26 April; Waseca 2001 - 9 May, 16 May, 22 May; Waseca 2002 - 30 April, 16 May, 23 May; Westport 2001 - 10 May, 17 May, 21 May; and Westport 2002 - 29 April, 15 May, 22 May.

${ }^{b}$ Total precipitation accumulated over each 14 -d growing period.
} 
Continued Table 3.

\begin{tabular}{|c|c|c|c|c|c|c|c|}
\hline 9 & 2001 & Ames & 2 & $0.7(0.08)$ & 12 & 5.6 & Low precipitation at beginning. \\
\hline 10 & 2002 & Westport & 2 & $0.6(0.05)$ & 4 & 0.5 & $\begin{array}{l}\text { Low precipitation; inadequate throughout } \\
\text { growing period; low soil temperatures at } \\
\text { beginning. }\end{array}$ \\
\hline 11 & 2002 & Westport & 1 & $0.4(0.04)$ & 0 & 5.9 & $\begin{array}{l}\text { High precipitation; inadequate soil } \\
\text { temperatures. }\end{array}$ \\
\hline 12 & 2002 & Waseca & 1 & $0.3(0.03)$ & 0 & 2.5 & $\begin{array}{l}\text { Low precipitation; inadequate soil } \\
\text { temperatures. }\end{array}$ \\
\hline
\end{tabular}

${ }^{a}$ Planting dates 1, 2, and 3 were as follows: Ames 2001 - 19 April, 24 April, 30 April; Ames 2002 - 13 April, 20 April, 26 April; Waseca 2001 - 9 May, 16 May, 22 May; Waseca 2002 - 30 April, 16 May, 23 May; Westport 2001 - 10 May, 17 May, 21 May; and Westport 2002 - 29 April, 15 May, 22 May.

${ }^{b}$ Total precipitation accumulated over each 14 -d growing period.

plant growth, over a specified period of time. A commonly accepted base temperature in the North Central United States is $10^{\circ} \mathrm{C}$ (WAN et al., 1999; HANSEN, 1986; HANsen et al., 1983; JENKInson, 1980). Therefore, our soil temperature data were converted to belowground GDD assuming a base temperature of $10^{\circ} \mathrm{C}$. A traditional use of GDD is to calculate the cumulative sum of all positive degree days over a year, with temperatures below the base temperature accumulating no degree days (CASTELAN-ESTRADA et al., 2002; LoBIT et al., 2001; LUOMAJOKI, 1995). We tested the accumulation of belowground GDD over the 14-d growing period.

Regression analysis was used to evaluate soil temperature effects on rooting. Clones were pooled by genomic group (Table 1), and regression models were fit to the data. Belowground GDD were used instead of aboveground GDD because soil temperature was much more stable than air temperature and we believe soil temperature had the most dramatic affect on rooting given the need for temperature-driven initiation of root primordia and utilization of stored reserves within the cutting. Least-squares regression analysis was used to examine the relationship between belowground GDD and each rooting parameter. Linear and quadratic terms were fit to the data and the choice of appropriate model was determined according to significance of an F-test with the addition of the quadratic term (NETER et al., 1996).

\section{Results}

The accumulation of belowground GDD across each 14-d growing period ranged from 0 to 88 . Minimum soil temperatures at a depth of $20 \mathrm{~cm}$ varied up to $4{ }^{\circ} \mathrm{C}$ in a 24 -h period. The differential between aboveground GDD and belowground GDD was variable at each site early in the growing season but stabilized as soil temperatures at $20 \mathrm{~cm}$ below the soil surface increased. No trend emerged relating rooting with the differential between aboveground GDD and belowground GDD.

We hypothesized responses among genomic groups to the accumulation of thermal units would significantly differ, although differences among genomic groups were negligible $(P>0.05)$. Least-squares regression models indicated similar responses among genomic groups and, thus, similar predictive functions for root dry weight, number of roots, total root length, and mean root length. All quadratic terms were non-significant $(P>0.05)$. Thus, simple linear regression models were fit to the data. All rooting traits exhibited similar trends. However, mean root length was used in the subsequent analysis because of relatively higher coefficients of determination than for other rooting traits and because all rooting traits were highly positively correlated (Table 2). Mean root length increased with increasing belowground GDD across genomic groups (Fig. 1). Our results did not show any signs of exceeding an upper optimal temperature for root growth.

Analysis of maximum and minimum soil temperatures, along with belowground GDD and precipitation events, indicated a minimum of four days with at least $4{ }^{\circ} \mathrm{C}$ above the $10^{\circ} \mathrm{C}$ base temperature (i.e. indicating a new base temperature of $14^{\circ} \mathrm{C}$ ) were needed for cuttings to produce greater than average $(0.97 \pm 0.02 \mathrm{~cm})$ mean root length (Table 3). Data for root dry weight, number of roots, and total root length followed similar trends. Cuttings subjected to less than four days above $14^{\circ} \mathrm{C}$, regardless of the amount of precipitation, did not exhibit comparable root production. Nevertheless, cuttings subjected to belowground GDD at $14^{\circ} \mathrm{C}$ also required adequate precipitation in order to exhibit increased root initiation and growth. Mean root length $(0.7 \pm 0.08 \mathrm{~cm})$ of the Ames 2001 planting date 2 was very low, despite having $12 \mathrm{~d}$ above the $14{ }^{\circ} \mathrm{C}$ threshold (Fig. 2). This growing period had very low precipitation at the start. In contrast, cuttings of the Ames 2002 planting date 1 exhibited the second highest mean root length $(1.7 \pm$ $0.11 \mathrm{~cm}$ ) yet only had four days above $14^{\circ} \mathrm{C}$. Precipitation also was low during this growing period. However, the precipitation was sufficiently dispersed throughout the $14 \mathrm{~d}$. Cuttings planted on many other planting dates with low to moderate precipitation had above-average mean root length when precipitation was sufficiently 
dispersed across the 14-d growing period (Table 3). For example, cuttings of the 2002 Westport date 3 planting only received $0.7 \mathrm{~cm}$ of precipitation during $14 \mathrm{~d}$ of growth (Fig. 3), yet mean root length $(1.1 \pm 0.08 \mathrm{~cm})$ was tied for the fifth best overall. There was one case where it appeared too much precipitation inhibited rooting. The 2001 Waseca date 2 planting had eight days above $14{ }^{\circ} \mathrm{C}$, along with total precipitation of $8.3 \mathrm{~cm}$ (Fig. 4). These values indicated conditions for enhanced rooting were met. However, evaluation of precipitation events shows almost all of the precipitation came in the middle of the growing period concurrently with decreasing soil temperatures. Nevertheless, in general, sufficiently dispersed precipitation events and a daily belowground temperature of $14{ }^{\circ} \mathrm{C}$ led to greater root initiation and growth of poplar cuttings.

\section{Discussion}

Our results showed soil temperature and amount of precipitation governed root growth at all sites. Because we harvested $14 \mathrm{~d}$ after planting, the cuttings were not

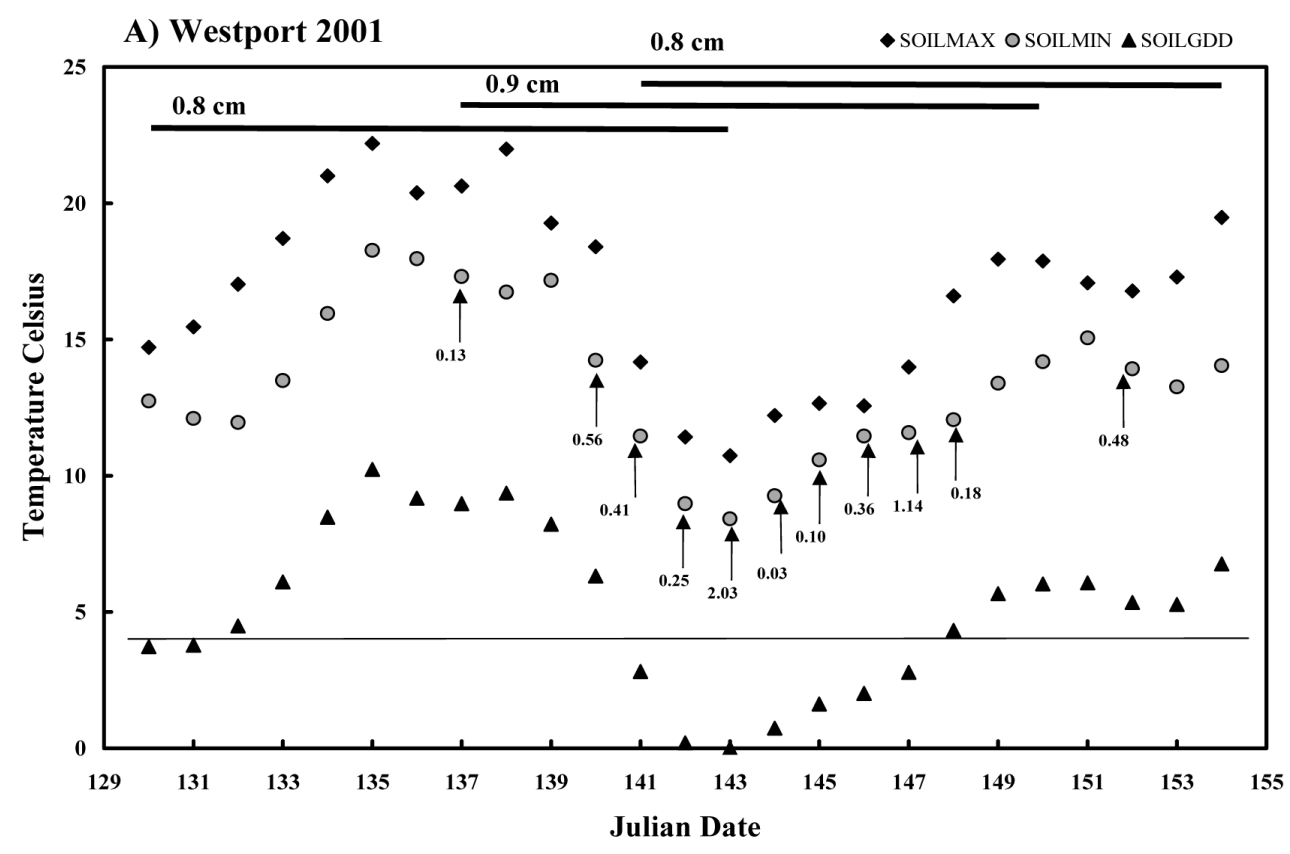

B) Westport 2002

- SOILMAX O SOILMIN $\Delta$ SOILGDD

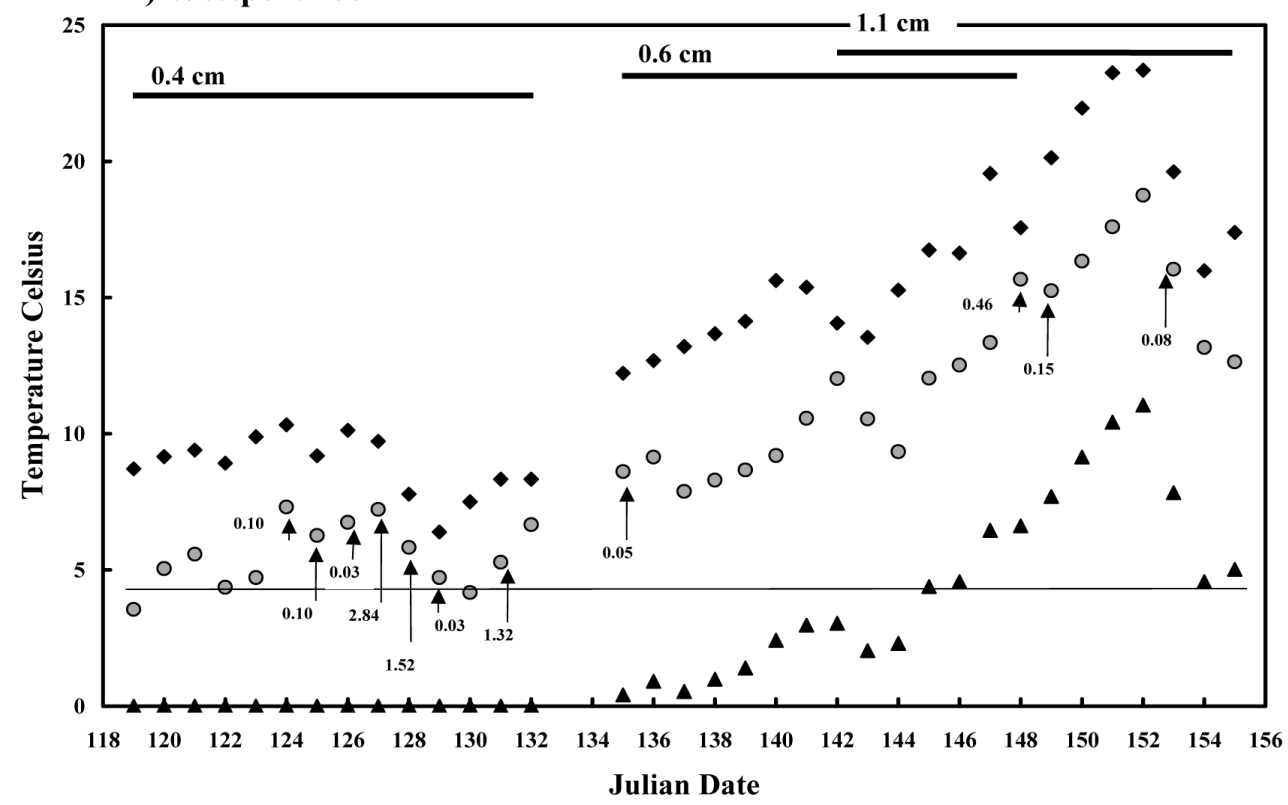

Figure 3. - Maximum soil temperature (SOILMAX), minimum soil temperature (SOILMIN), belowground growing degree days (SOILGDD), and precipitation events (denoted with value in $\mathrm{cm}$ below each arrow) at Westport, Minnesota, USA $\left(45.7^{\circ} \mathrm{N}, 95.2^{\circ} \mathrm{W}\right)$ during 2001 (A) and 2002

(B). Each black bar on the top of the figure represents one planting date, with the mean root length of 252 cuttings listed above it. 

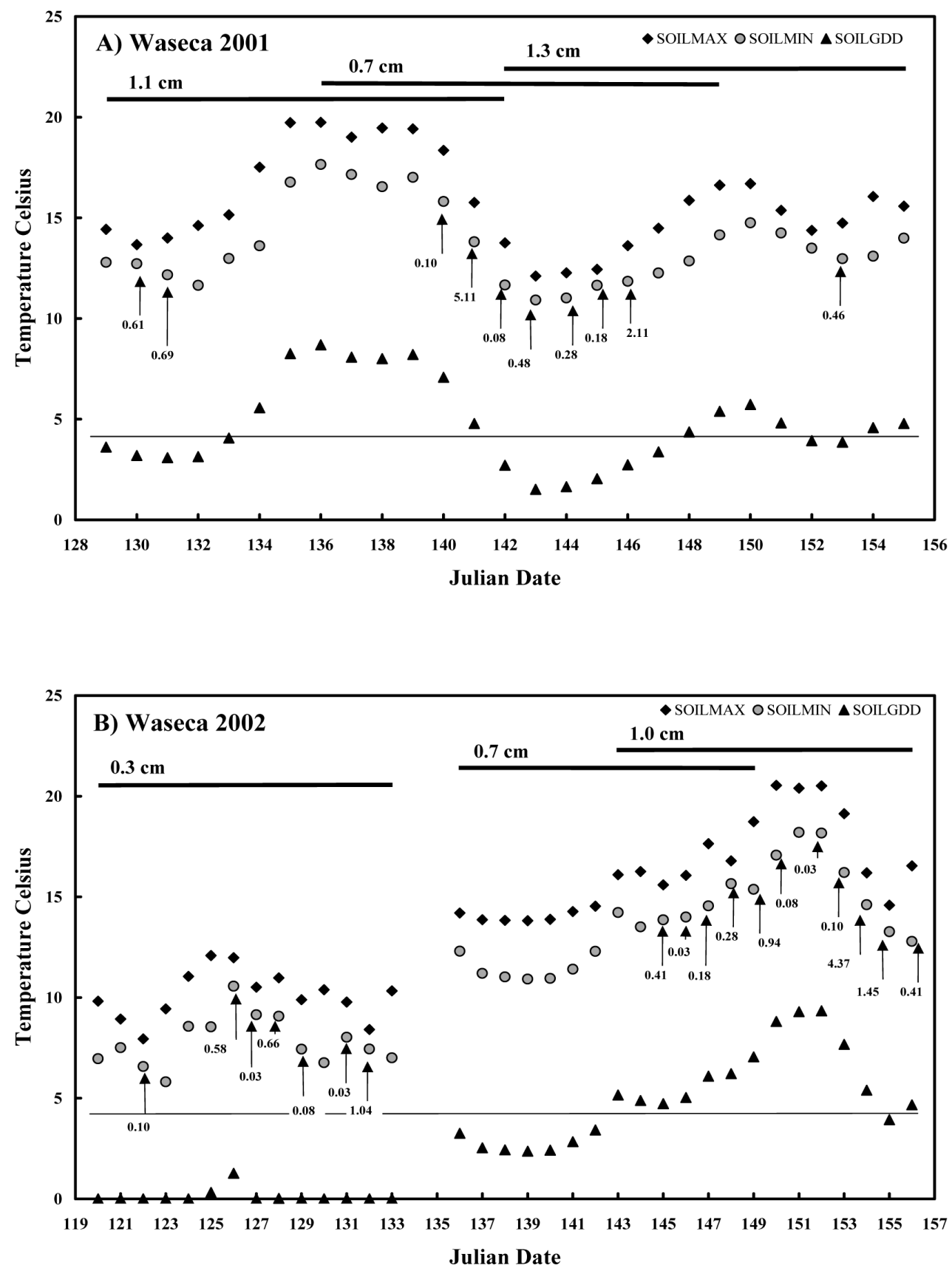

Figure 4. - Maximum soil temperature (SOILMAX), minimum soil temperature (SOILMIN), belowground growing degree days (SOILGDD), and precipitation events (denoted with value in $\mathrm{cm}$ below each arrow) at Waseca, Minnesota, USA $\left(44.1^{\circ} \mathrm{N}, 93.5^{\circ} \mathrm{W}\right)$ during 2001 (A) and 2002 (B). Each black bar on the top of the figure represents one planting date, with the mean root length of 252 cuttings listed above it.

subjected to long-term environmental effects. Although we did not know when during the $14 \mathrm{~d}$ of growth the roots initiated and emerged from the cuttings, initial growth most likely depended on reserves of carbohydrates stored in the cutting and how the cutting responded to environmental stimuli such as soil temperature, soil moisture, soil strength, and soil aeration. Future studies could be designed that allow for continual assessment of rooting under different soil conditions.

An original hypothesis was that increasing belowground GDD would promote rooting until reaching an upper threshold associated with the inhibition of root initiation. However, the belowground GDD never reached a threshold warm enough to test our hypothesis. Root initiation is a function of root primordia formation and rate of cell division (PREECE, 1993; DYKEMAN, 1976). Likewise, root development includes cell elongation, differentiation, and cell division. We believed root initiation and root development would occur at different temperature thresholds, with initiation requiring warmer temperatures than development. Similarly, Preece (1993) and Dykeman (1976) conjectured two 
optimum temperatures governed total root growth. Root growth required a brief period of warm temperatures for initiation followed by a sustained period of cooler temperatures for elongation. DYKEMAN (1976, page 202) cited another study (VERSLUYS, 1927) where the highest level of root initiation was at $27^{\circ} \mathrm{C}$ and subsequent root elongation took place best at $17^{\circ} \mathrm{C}$. In contrast, an alternative model in mugo pine (Pinus mugho Turra) showed root responses lagged 2 to $5 \mathrm{~d}$ behind temperature extremes (HiLton and MAson, 1971). Nevertheless, root initiation and root development of our genomic groups failed to exhibit similar trends to these studies.

Further investigation of the differential between aboveground GDD and belowground GDD on total plant production is warranted. Although the results of this study were inconclusive with respect to the effects of the differential between aboveground GDD to belowground GDD on root production and growth, controlled environment studies should be conducted that maintain constant but different temperatures aboveground and belowground. Testing the aboveground and belowground growth of cuttings under different temperature regimes may lead to the identification of specific temperature and moisture optima for each, based on the genotype being used. Soil and air temperature affect the success of rooting from dormant cuttings, as root metabolism, that is temperature-driven, governs root growth and uptake (WIERSUM, 1980). Combinations of cold soil temperatures and warm air temperatures may cause reduced vigor due to the lack of ability to conduct water fast enough to meet transpirational demands of the leaves and shoots (LANDHÄUSSER et al., 2002; WAN et al., 1999). Erratic soil temperatures in our study most likely led to varying root initiation and root development, with warmer temperatures associated with above-average rooting. Proper temperatures facilitate activity within root primordia, which support lateral and adventitious root initiation and root development (LuxovA, 1984). Cold temperatures below minimum thresholds reduce cell division and associated root initiation. For example, root growth of $P$. tremuloides was inhibited at and below $5{ }^{\circ} \mathrm{C}$ (LANDHÄUsSER et al., 2001; WAN et al., 1999). Rooting likely decreased because the rate of metabolism within the cutting was not sufficient. In addition, temperatures that are too warm inhibit growth due to accelerated respiration levels that deplete stored reserves within the cutting. Our cuttings planted at Ames during 2001 (planting date 2) and at Waseca during 2002 (planting date 2) experienced high temperatures yet exhibited mean root length $(0.7 \pm 0.08 \mathrm{~cm}, 0.7 \pm 0.05 \mathrm{~cm}$, respectively) below the overall mean $(0.97 \pm 0.02 \mathrm{~cm})$. DESRocheRs et al. (2002) evaluated coarse and fine root respiration in $P$. tremuloides and observed increased respiration levels at higher soil temperatures. Respiration has a temperature coefficient $\left(Q_{10}\right)$ of about two, which means the amount of carbon dioxide $\left(\mathrm{CO}_{2}\right)$ given off doubles for every $10^{\circ} \mathrm{C}$ increase in temperature. Levels of $\mathrm{Q}_{10}$ near four are reported for $P$. tremuloides (DEsRochers et al., 2002). Respiration is necessary for rooting because the cutting must release energy to facilitate growth. Yet excessive respiration levels have result- ed in desiccation and death of cuttings (PREECE, 1993; KeSTER, 1970). The success of cuttings depends on the balance between respiration and photosynthesis (KESTER, 1970).

Soil moisture content and water availability are key issues affecting root growth across variable sites. Successful rooting requires an acceptable balance between moisture content and water availability. Too much water causes conditions of poor aeration, which reduces growth (WIERSUM, 1980). Lack of water leads to desiccation and death. Our results showed sufficiently dispersed precipitation events leading to fewer periods of unavailable water resulted in rooting success. However, some Populus species exhibited drought resistance following development of a root system (HARVEY and VAN DEN DrIEssche, 1999; STRONG and HANSEN, 1991). TschAPLINSKI et al. (1998) tested the drought resistance of two interspecific clones of poplar hybrids ( $P$. deltoides x P. nigra 'DN') and (P. trichocarpa \% P. deltoides 'TD'). The DN clone exhibited higher levels of drought resistance than the TD clone. The DN clone allocated more carbon to the roots during periods of drought, in addition to sustaining efficient stomatal regulation. The larger root system of the DN clone occupied more soil space and thus captured higher levels of available water. PREGITZER et al. (1993) tested the rooting response of trees growing in a mixed hardwood forest to water and nitrogen applied for 20 and $40 \mathrm{~d}$ and found the increase of available water over the 40-d duration resulted in greater root production than over the 20 - $d$ duration. Root growth of flax (Linum usitatissimum L.) also increased at higher soil moisture contents (Newman, 1966). Rhodenbaugh and Pallardy (1993) tested three hybrid poplar clones in their ability to grow in soils lacking and containing adequate water. Although none of the clones significantly outperformed any of the others in dry soil, they all exhibited the trend of increasing root and shoot growth with increasing soil moisture. Root length ranged from 161.3 to $660.3 \mathrm{~cm}$ and 31.7 to $86.1 \mathrm{~cm}$ for moist and dry soils, respectively. Future studies could be designed to test for rooting ability during periods of drought and to further test our hypothesis of the need for sufficiently dispersed precipitation.

\section{Conclusion}

Detailed quantitative genetic analysis describing the variation among clones within genomic groups for root dry weight, number of roots, total root length, and mean root length was described by ZALESNY et al. (2005). Nevertheless, for the current study, all rooting traits increased with increasing belowground GDD for all genomic groups. Least-squares regression models indicated similar responses among genomic groups and similar predictive functions for each rooting trait. Root growth did not plateau within the limits of the belowground GDD observed, which suggested upper temperature limits inhibiting rooting were not met. The interaction of soil temperature and precipitation governed rooting of these clones. A minimum of four days above $14^{\circ} \mathrm{C}$, along with sufficiently dispersed precipitation, were 
needed in order to sustain above-average levels of rooting. Cuttings subjected to less than four days above $14^{\circ} \mathrm{C}$, regardless of soil moisture, did not exhibit comparable root dry weight, number of roots, total root length, and mean root length.

\section{Acknowledgements}

This research was funded by the USDA Forest Service North Central Research Station, subcontract 19XSZ269C with the Bioenergy Feedstock Development Program of the United States Department of Energy at the Oak Ridge National Laboratory; the Iowa Agriculture and Home Economics Experiment Station, Ames, Iowa, Project No. 3905, and supported by McIntire Stennis and state of Iowa funds; and a Grant-in-Aid of Research from Sigma Xi, the Scientific Research Society. We thank the following people for helpful comments on earlier versions of this manuscript: ARDEN CAMPBELl, MARK ColEMAN, RoB Doudrick, Alex Friend, Bill Headlee, Assibi Mahama, Ken Moore, Jan Thompson, Adam Wiese and Jill ZALESNY.

\section{Literature Cited}

Allen, R. M. and A. L. McComB (1956): Rooting of cottonwood clones. USDA For. Serv. Occ. Pap. SO-OP-151.

BlOOMBERG, W. J. (1963): The significance of initial adventitious roots in poplar cuttings and the effect of certain factors on their development. For. Chron. 39: 279-289.

BradshaW, H. D., JR. (1996): Molecular genetics of Populus, pp. 183-199. In: R. F. Stettler, H. D. BRAdShaW, JR., P. E. Heilman, and T. M. Hinckley (eds). Biology of Populus and its implications for management and conservation. Part I, Chapter 8. NRC Research Press, National Research Council of Canada, Ottawa, Ontario K1A 0R6, Canada.

Castelan-Estrada, M., P. Vivin and J. P. Gaudillere (2002): Allometric relationships to estimate seasonal above-ground vegetative and reproductive biomass of Vitis vinifera L. Ann. Bot. 89: 401-408.

Davies, F. T., JR. and H. T. HARTMAnN (1988): The physiological basis of adventitious root formation. Acta Hort. 227: $113-120$.

DesRochers, A. and B. R. Thomas (2003): A comparison of pre-planting treatments on hardwood cuttings of four hybrid poplar clones. New For. 26: 17-32.

DesRochers, A., S. M. LANDhäUsser and V. J. LiefFers (2002): Coarse and fine root respiration in aspen (Populus tremuloides). Tree Physiol. 22: 725-732.

Domisch, T., L. Finer and T. LEHTO (2001): Effects of soil temperature on biomass and carbohydrate allocation in Scots pine (Pinus sylvestris) seedlings at the beginning of the growing season. Tree Physiol. 21: 465-472.

Dunn, D. E., J. C. Cole and M. W. Smith (1996): Timing of Pistacia chinensis Bunge. rooting using morphological markers associated with calendar date and degree days. J. Amer. Soc. Hort. Sci. 121: 269-273.

DYKEMAN, B. (1976): Temperature relationship in root initiation and development of cuttings. Comb. Proc. Intl. Plant Prop. Soc. 26: 201-207.

Eisensmith, S. P., A. L. Jones and J. A. Flore (1980): Predicting leaf emergence of 'Montmorency' sour cherry from degree-day accumulations. J. Amer. Soc. Hort. Sci. 105: $75-78$.
Fennell, A., P. H. Li and A. H. MARkHART, III. (1990): Influence of air and soil temperature on water relations and freezing tolerance of spinach (Spinacia oleracea). Physiol. Plant. 78: 51-56.

Haissig, B. E. and T. D. DAVIS (1994): A historical evaluation of adventitious rooting research to 1993, pp. 275-331. In: T. D. DAVIS and B. E. HAISsig (eds). Biology of adventitious root formation. Plenum Press, New York.

Haissig, B. E., Davis, T. D. and Riemenschneider, D. E. (1992): Researching the controls of adventitious rooting. Physiol. Plant. 84: 310-317.

Hansen, E. A. (1986): Planting date affects survival and height growth of hybrid poplar. For. Chron. 62: 164-169.

HANSEN, E. A. and H. M. PhipPs (1983): Effect of soil moisture tension and preplant treatments on early growth of hybrid Populus hardwood cuttings. Can. J. For. Res. 13: 458-464.

Hansen, E. A., L. Moore, D. A. Netzer, M. Ostry, H. Phipps and J. ZaVITKOVSKI (1983): Establishing intensively cultured hybrid poplar plantations for fuel and fiber. USDA For. Serv. Gen. Tech. Rep. NC-GTR-78.

Hansen, E. A., D. A. Netzer and D. N. Tolsted (1993): Guidelines for establishing poplar plantations in the north-central U.S. USDA For. Serv. Res. Note NC-RN363.

Hartmann, H. T., D. E. Kester, F. T. Davies, JR. and R. L. GENEVE (1997): Plant propagation: principles and practices. Sixth Edition. Prentice Hall, Upper Saddle River, New Jersey.

Harvey, H. P. and R. van Den DRIEssche (1999): Poplar nutrient resorption in fall or drought: influence of nutrient status and clone. Can. J. For. Res. 29: 1916-1925.

Hilton, R. J. and G. F. MASON (1971): Responses of mugho pine roots to soil temperature and of bolleana poplar roots to light. HortScience 6: 43-45.

Husain, S. A., D. W. Rose and S. O. Archibald (1998): Identifying agricultural sites for biomass energy production in Minnesota. Biomass Bioenergy 15: 423-435.

JENKINSON, J. L. (1980): Improving plantation establishment by optimizing growth capacity and planting time of western yellow pines. USDA For. Serv. Res. Pap. PSW-RP-154.

Kester, D. E. (1970): Temperature and plant propagation. Comb. Proc. Intl. Plant Prop. Soc. 20: 153-163.

LANDhÄUsser, S. M., A. DesRochers and V. J. LiefFers (2001): A comparison of growth and physiology in Picea glauca and Populus tremuloides at different soil temperatures. Can. J. For. Res. 31: 1922-1929.

LANDHÄUsser, S. M., T. M. MuHSIN and J. J. ZWIAZEK (2002): The effect of ectomycorrhizae on water relations in aspen (Populus tremuloides) and white spruce (Picea glauca) at low soil temperatures. Can. J. Bot. 80: 684-689.

Lobit, P., P. SoIng, M. Genard and R. HABIB (2001): Effects of timing of nitrogen fertilization on shoot development in peach (Prunus persica) trees. Tree Physiol. 21: $35-42$.

LuOMAJOKI, A. J. (1995): Phenological measurements of microsporogenesis in trees. Tree Physiol. 15: 499-505.

Luxova, M. (1984): The integration of growth activity in vegetatively propagated poplar during the establishment year. Biol. Plant. 26: 433-440.

Neter, J., M. H. Kutner, C. J. Nachtsheim and W. WASSERMAN (1996): Applied linear statistical models. Fourth Edition. McGraw-Hill, New York. 
Netzer, D. A., D. Tolsted, M. E. Ostry, J. G. Isebrands, D. E. RIEMENSChNEIDER and K. T. WARD (2002): Growth, yield, and disease resistance of 7- to 12-year-old poplar clones in the north central United States. USDA For. Serv. Gen. Tech. Rep. NC-GTR-229.

NEWMAN, E. I. (1966): Relationship between root growth of flax (Linum usitatissimum) and soil water potential. New Phytol. 65: 273-283.

Newman, J. E., B. O. Blair, R. F. Dale, L. H. Smith, W. L. STIRM and L. A. SchAAL (1968): Growing degree days. Crops Soils December: 9-12.

PAVel, E. W. and E. Fereres (1998): Low soil temperatures induce water deficits in olive (Olea europaea) trees. Physiol. Plant. 104: 525-532.

Petersen, L. and H. Phipps (1976): Water soaking pretreatment improves rooting and early survival of hardwood cuttings of some Populus clones. Tree Plant. Not. 27: 12-22.

Phipps, H. M., E. A. Hansen and A. S. Fege (1983): Preplant soaking of dormant Populus hardwood cuttings. USDA For. Serv. Res. Pap. NC-RP-241.

PREECE, J. E. (1993): Basics of propagation by cuttings temperature. Comb. Proc. Intl. Plant Prop. Soc. 43: 441-444.

Pregitzer, K. S., R. L. Hendrick and R. Fogel (1993): The demography of fine roots in response to patches of water and nitrogen. New Phytol. 125: 575-580.

Rhodenbaugh, E. J. and S. G. PALlardy (1993): Water stress, photosynthesis and early growth patterns of cuttings of three Populus clones. Tree Physiol. 13: $213-226$

Riemenschneider, D. E. and E. O. BAUER (1997): Quantitative genetic analysis of adventitious root forming ability in Populus trichocarpa (TORR ET. GRAY), pp. 193-201. In: Altman and WAISEL (eds). Biology of root formation and development. Chapter 24. Plenum Press, New York.

Riemenschneider, D. E., H. E. Stelzer and G. S. Foster (1996): Quantitative genetics of poplars and poplar hybrids, pp. 159-181. In: R. F. STETTLER, H. D. BRADSHAW JR., P. E. HEILMAN and T. M. HiNCKLEY (eds). Biology of Populus and its implications for management and conservation. Part I, Chapter 7. NRC Research Press, National Research Council of Canada, Ottawa, Ontario K1A 0R6, Canada.

Riemenschneider, D. E., W. E. Berguson, D. I. Dickmann, R. B. Hall, J. G. Isebrands, C. A. Mohn, G. R. Stanosz and G. A. Tuskan (2001): Poplar breeding and testing strategies in the north-central U.S.: demonstration of potential yield and consideration of future research needs. For. Chron. 77: 245-253.

SAS InstituTE, INC. (2000): SAS/STAT ${ }^{\mathrm{TM}}$ User's Guide. Version 8. Cary, North Carolina, SAS Institute, Inc.

Stanturf, J. A., C. van Oosten, D. A. Netzer, M. D. ColeMAN and C. J. PORTwOoD (2001): Ecology and silvicul- ture of poplar plantations, pp. 153-206. In: D. I. DickMANN, J. G. ISEBRANDS, J. E. ECKENWALDER and J. RichaRdson (eds). Poplar culture in North America. Part A, Chapter 5. NRC Research Press, National Research Council of Canada, Ottawa, Ontario K1A 0R6, Canada.

Strong, T. and E. A. HAnsen (1991): Response of three Populus species to drought. USDA For. Serv. Res. Pap. NC-RP-302.

Tschaplinski, T. J., G. A. Tuskan, G. M. Gebre and D. E. ToDD (1998): Drought resistance of two hybrid Populus clones grown in a large-scale plantation. Tree Physiol. 18: $653-658$.

VERSLUYs, M. C. (1927): Formation and growth of the roots of Hyacinthus orientalis. Verhandelingen der Koninklijke Akademie van Wetenschappen te Amsterdam, Afdeeling Natuurkunde (Tweede sectie) XXV 4: 63-81.

VINocuR, M. G. and J. T. RiTchiE (2001): Maize leaf development biases caused by air-apex temperature differences. Agron. J. 93: 767-772.

WAN, X., S. M. LANDHÄUsser, J. J. ZwiAZEK and V. J. LiefFERS (1999): Root water flow and growth of aspen (Populus tremuloides) at low root temperatures. Tree Physiol. 19: $879-884$.

Wiersum, L. K. (1980): The effect of soil physical conditions on roots and uptake. Acta Hort. 92: 111-122.

Wilcox, J. R. and R. E. FARMER, JR. (1968): Heritability and $\mathrm{C}$ effects in early root growth of eastern cottonwood cuttings. Heredity 23: 239-245.

ZALESNY, R. S., JR. (2003): Genetic and environmental effects on rooting ability of dormant unrooted hybrid poplar cuttings. PhD Dissertation, Iowa State Univ., Ames, Iowa.

Zalesny, R. S., JR., D. E. Riemenschneider and E. O. BAUER (2000): Analysis of genetic and environmental effects on hybrid poplar rooting in central and northern Minnesota, USA. In $21^{\text {st }}$ Session of the International Poplar Commission (IPC 2000): poplar and willow culture: meeting the needs of society and the environment; September 24-28, 2000; Vancouver, Washington. USDA For. Serv. Gen. Tech. Rep. NC-GTR-215.

Zalesny, R. S., JR., R. B. Hall, E. O. Bauer and D. E. RIEMENSCHNEIDER (2003): Shoot position affects root initiation and growth of dormant unrooted cuttings of Populus. Silvae Genet. 52: 273-279.

Zalesny, R. S., JR., E. O. Bauer and D. E. RiemenSCHNEIDER (2004): Use of belowground growing degree days to predict rooting of dormant hardwood cuttings of Populus. Silvae Genet. 53: 154-160.

Zalesny, R. S., JR., D. E. Riemenschneider and R. B. HALL (2005): Early rooting of dormant hardwood cuttings of Populus: analysis of quantitative genetics and genotype $x$ environment interactions. Can. J. For. Res. 35: $918-929$. 